\title{
Investing in International Graduate Students for the Scientific Endeavour Keeps the United States Competitive
}

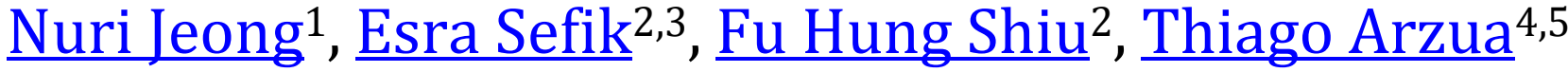 \\ ${ }^{1}$ Georgia Institute of Technology and Emory University, Wallace H. Coulter Department of Biomedical \\ Engineering, Atlanta, GA \\ 2Emory University, Department of Human Genetics, Atlanta, GA \\ ${ }^{3}$ Emory University, Department of Psychology, Atlanta, GA \\ ${ }^{4}$ Medical College of Wisconsin, Department of Cell Biology, Neurobiology \& Anatomy, Milwaukee, WI \\ 5Medical College of Wisconsin, Department of Physiology, Milwaukee, WI \\ https://doi.org/10.38126/ISPG180304 \\ Corresponding author: tarzua@mcw.edu \\ Keywords: international doctoral students; student visa; immigration; federal funding; Congress
}

\begin{abstract}
Executive Summary: As the global scientific and engineering powerhouse, the United States has pioneered numerous inventions such as the telephone, alternating current, radio broadcasting, and controlled nuclear chain reactions. Some may be surprised to find that these were products of immigrants, who pushed the boundaries of science and technology. In the past years, however, the U.S. has been losing its competitive advantage in the global labor market. A key reason for this is that the U.S. is failing to attract and retain international graduate students in STEM fields. Historically, a large portion of these students stayed after graduation and drove innovations that fueled the nation's trillion-dollar economy. That trend is changing, with many now opting to go elsewhere for their graduate education. Critical flaws in U.S. visa and immigration policy and a lack of federal funding mechanisms for international graduate students are exacerbating this trend. As a result, the U.S. is losing promising junior scientists to other countries with more aggressive foreign recruitment strategies. To counter this trend, we outline in detail the areas with room for growth and propose policy solutions to be implemented by the federal government. These solutions will help the U.S. excel in STEM research workforce diversity, equality, cultural competence, and ultimately, retain its global leadership.
\end{abstract}

\section{The United States is losing its scientific research and innovation edge}

According to the most recent reports by the National Center for Science and Engineering Statistics, there were 112,755 international students enrolled in doctoral science, engineering, and health at the United States (U.S.) institutions in the fall of 2019. Among the total STEM doctorate recipients in 2019, $39.4 \%$ were international students with nonimmigrant visas (NCSES 2019). Despite the U.S. being the top destination country of international graduate students and the largest producer of non-citizen doctorate holders by number, the country has not kept up with recent trends. The number of international students seeking advanced degrees in countries other than the U.S. has grown rapidly since 2010. Over the past two decades, the number of international graduate students enrolled in Canada and Australia has increased substantially, whereas the U.S. has maintained modest growth levels (Figure 1). As other countries more actively recruited and invested in foreign students, the share of the world's international students enrolled in the U.S. dropped from $25 \%$ in 2000 to just $19 \%$ in 2014 (NSB 2018), with the decline predicted to continue. 

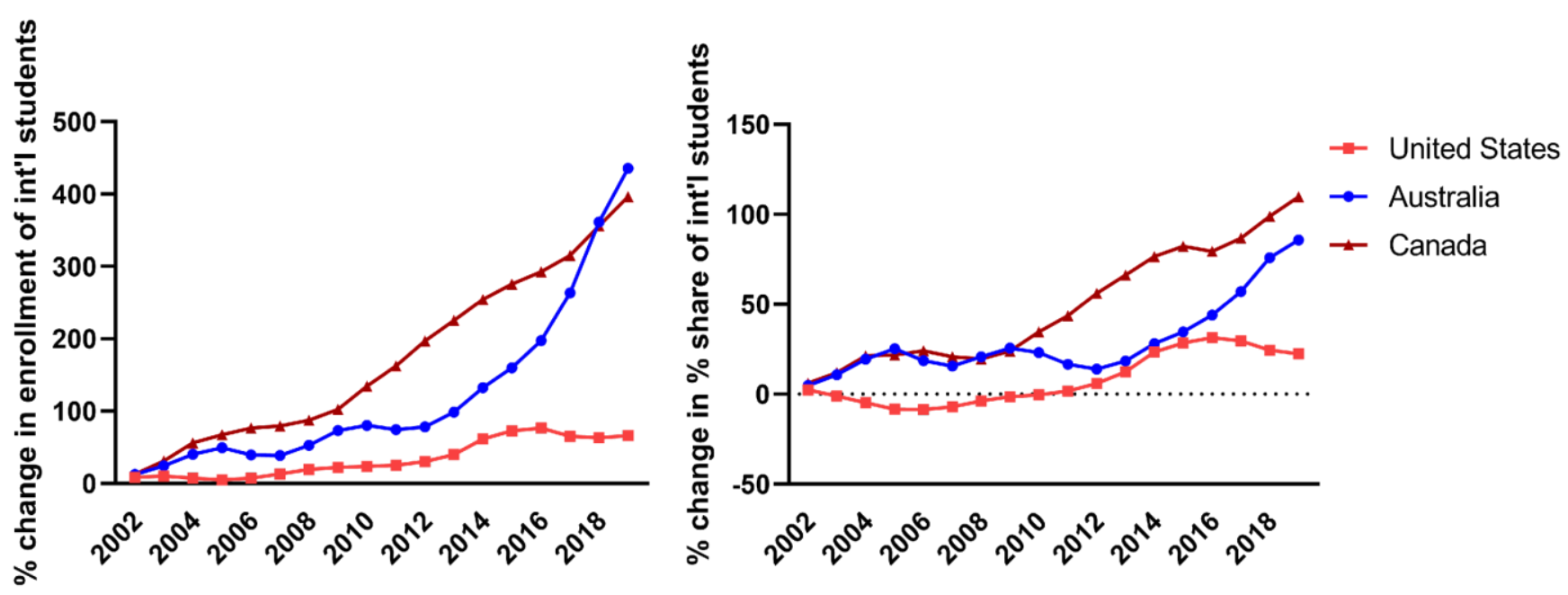

Figure 1: The U.S. is losing its competitive edge with its international enrollment in STEM. Left, percent change from 2001 in the number of international students enrolled in Ph.D. and master's programs in the STEM fields. Right, percentage change from 2001 in the percent of international students as a share of total students enrolled in Ph.D. and master's programs in the STEM fields. Data were retrieved from the sources shown in appendix.

The U.S. share in research and development on the global stage has also shrunk from $37 \%$ in 2000 to 25\% in 2017 (NCSES 2020). Curiously, the federal research and development budget between fiscal years 2000 and 2017 more than doubled, from $\$ 75$ billion to $\$ 152$ billion. Thus, improving research productivity in the U.S. requires a different strategy rather than a mere increase in funding. While increased federal research funding is a movement in the right direction, a long-term solution must strategically target specific groups of scientists and engineers. We propose that early career foreign scientists have untapped potential to boost STEM research performance in the U.S. Not only is targeting international graduate students a cost-effective option, but it is true to the American value of meritocracy.

Reforming the immigration system is clearly at the forefront of American interests, as the Biden administration introduced its proposed legislative bill, the U.S. Citizenship Act of 2021. However, lawmakers are currently approaching the bill in a piecemeal fashion (Jaffe 2021), which means significant delays are expected as it is integrated into concrete policies. More importantly, the bill does not cover all factors that contribute to the downward trend in attracting and retaining international graduate students. Our goal is to discuss key issues that many international students are facing, namely limitations of current visa and immigration policies and the lack of U.S.-government-funded training opportunities. While we, as current international doctoral students, focus our proposal on doctoral international students, our recommendations can be broadly applied to all degree-level students.

\section{Barriers for international graduate students in the U.S.}

\section{i. U.S. visa and immigration policy toward international students}

The lengthy, convoluted, and uncertain path to U.S. permanent residency is a key barrier that Congress can correct immediately to help increase and retain foreign talent. A host country's visa and immigration policy critically influence the choice of study abroad destinations (Eder, Smith, and Pitts 2010; Chen 2007). For instance, the strict visa and immigration policies in the U.S. were found to motivate East Asian international graduate students to choose Canada over their erstwhile top-choice country U.S. (Chen 2007). Consistent with this observation, the ease of visa and immigration policy was reported to be a major factor for students determining a destination country for higher education (Yang 2007).

Most international graduate students studying in the U.S. do so through temporary nonimmigrant visas, such as F-class visas. One of the main criteria for obtaining an F-class visa is the applicant's proof of intent to return to their home country after 
graduation, in accordance with Section 214(b) in the Immigration and Nationality Act (National Research Council 2005). However, it can be difficult to prove that the applicants have no intention to immigrate, especially if they have relatives living in the U.S. (National Research Council 2005). Without standardized practices for determining nonimmigrant intent, consular officers have discretion over the decision (National Research Council 2005). To make matters worse, most young graduate students at the early stages of their careers are unable to provide proof of financial ties to their home countries, such as investments or property, as they are advised to submit supporting documents. Consideration of financial resources as proof of nonimmigrant intent disproportionately affects lowincome foreign students who have achieved acceptance to a U.S. institution through academic merit, hindering the expansion of socioeconomic diversity in the STEM fields.

An inherent disparity also exists in the length of visa application processing times and validation periods based on the applicant's country of origin. For example, those from the Middle East and Muslimmajority countries, such as Iran, tend to have a longer delay in processing (six months or longer) and a shorter validation period, which ranges from singleentry to 12 months. In contrast, students from most other countries are allowed sixty months of legal entry (U.S. Department of State). Along the same lines, Ewers and Lewis (2008) found that the post9/11 climate in the U.S. resulted in international students being treated as a national security risk based on ethnicity, race, nationality, and religion. Unsurprisingly, many are now opting to study in other more welcoming countries like Australia and Canada (Urais and Yeakey 2008). These outdated, discriminatory policies cost little to nothing to change and can have a tremendous impact on how the U.S. is perceived by aspiring students and workers from abroad.

Given the extent of resources invested into training these students, the U.S. should incentivize such highly skilled graduates to stay in the country and join the STEM workforce through efficient work authorization and permanent residency pathways. Besides a myriad of difficulties associated with student visa applications at the start of graduate education, additional challenges greet international
STEM students as they integrate into the U.S. workforce after degree completion. There is currently no direct pathway to permanent residency post-graduation. The only way recent graduates of foreign status can work legally in the U.S. right now is through the Optional Practical Training (OPT) program. Authorized by the U.S. Citizenship and Immigration Services, the OPT program allows STEM graduates to work for up to three years after graduation. For longer-term stay and a work permit in the U.S., permanent residency is required. Recent graduates typically elect to take the intermediate step of obtaining a temporary work visa such as the H1-B before transitioning to permanent residency. Options for obtaining permanent residency without the interim H1-B exist but they are deemed risky because there are no clear merit-based approval criteria. The average wait time of permanent residency applications is five to nine months (USCIS 2021) but can be as long as ten years for students from countries like India and China, which send large numbers of migrants to the U.S. (Roach and Skrentny 2021; Kandel 2020). Despite demands for H1-B visas, it is not easy to obtain one. Many U.S.-based employers are discouraged from hiring a non-U.S. citizen employee because of the hefty visa sponsorship fee of $\$ 6,470$ or more. Difficulty obtaining an H1-B visa is further exacerbated by annual caps imposed on high-skilled workers in the private sector. Non-profit organizations such as universities and colleges are exempt from the H1-B cap, and this discrepancy in the H1-B cap/exemption system also creates a divide in the STEM workforce. Furthermore, there is a critical need for STEM professionals in all sectors, given the estimated 3.5 million STEM jobs to be filled by 2025 (Lazio and Ford Jr., 2019).

After jumping through hoops to obtain legal employment authorization, foreign workers are challenged to fit in the American work culture that questions their fit. For example, in recent years, even the existence of the short-term OPT program has been threatened with several lawsuits claiming that the program harms American workers by creating "unfair competition" with foreign labor. We underscore the report that the National Foundation for American Policy has found no evidence for this argument (Zavodny 2019). In fact, new findings suggest that immigrants to the U.S. increase the demand for labor in many sectors of the economy, by 
creating new jobs (Azoulay et al. 2020). In addition, immigrants have launched over $50 \%$ of new U.S.based start-ups valued at over $\$ 1$ billion (Anderson 2018). Therefore, international graduate students must be considered not only as future workers but also as future entrepreneurs and innovators with a positive ripple effect on the U.S. economy and employment rate.

\section{ii. Lack of government funding for international graduate students in the U.S.}

Despite paying the same federal and state income taxes as domestic students, international graduate students in the U.S. are ineligible for all government fellowship opportunities available to U.S. citizens and permanent residents. International students are also barred from prestigious awards and conference travel grants by professional societies and private organizations if the funding comes from a federal source (e.g., The Ford Foundation Fellowship or the Society for Neuroscience's Neuroscience Scholars Program). Apart from the obvious monetary disadvantage, the non-monetary impact of this inequality is significant because missed opportunities for professional development make it difficult for a competitive job application. It is also antithetical to the value of fostering a meritocracy in higher education institutions.

There is room for improvement in the funding mechanisms for graduate students in the United States. Former U.S. President Donald Trump proposed approximately $\$ 142.2$ billion for research and development for the fiscal year 2021. The National Institutes of Health and the National Science Foundation together made up $31.1 \%$ of the funding, the second largest after the Department of Defense. This federal funding covers over half a million doctoral STEM students in total. Therefore, the scope of these expenditures is directly related to government policy. Although rarer, some international graduate students manage to secure overseas funding for their education. In some cases, this can create a legal obligation for degree recipients to return to and work in the country providing the funds. Because international graduate students are more likely to leave the U.S. upon graduation if funded by foreign sources (Bretschneider and Dai 2017), expanded U.S. government funding opportunities can directly counter the trending loss of international talent.
These factors form a network of obstacles and imbalances that weigh heavily against recruitment and retention of foreign talent and diversity, creating long-lasting effects. Studies suggest that junior scientists who secure funding at an early stage of their careers are more likely to receive future funding as established scientists (Heggeness et al. 2018). This ultimately translates to greater research productivity that benefits society. Hence, even if and when an international doctoral student decides to stay in the U.S. after graduation, the funding inequalities accumulate from an early career stage, and exacerbate the other inequalities. International students will thus select graduate programs with funding and training opportunities without citizenship requirements. Consequently, international students will cluster at a small number of well-funded universities that dominate the recruitment of new international talent. Qualified foreign nationals are also deterred from working in smaller U.S. cities that may need their talents more than large ones.

\section{Solutions to counter the negative trends}

\section{i. Non-monetary approaches to improving \\ international student recruitment, retention, and satisfaction}

The loss of international Ph.D. students upon completion of their degree programs represents a missed opportunity for the U.S. to realize a return on its investment. To counter this loss, we recommend restructuring the current visa and immigration policy (Figure 2). A new visa category for international graduate students with an exemption of Section 214(b), the intent to return, is an important first step toward this change. The Biden administration has proposed to permit dual intent for full-time postsecondary F-1 students. The dual intent proposal would allow the visa holders the intention to immigrate to the U.S. in the future while legally maintaining a nonimmigrant status presently. We fully support this initiative and commitment to a more welcoming atmosphere. In addition, the validity period of $\mathrm{F}-1$ visas must be matched to the duration of graduate study. This recommendation will lessen the financial and emotional burden for international students who must leave the country for renewal but have no guaranteed re-entrance. Another way to lessen the stress is to extend OPT authorization for up to six years, the maximum duration of stay in $\mathrm{H}-1 \mathrm{~B}$ 


\title{
Keeping the United States Competitive
}

\author{
Increased Funding Opportunities \\ Preliminary studies to \\ determine possible applicants \\ $(2$ \\ Open up funding currently not \\ available to $\mathrm{F}-1$ students
论 New opportunities focused on
倧 international recruitment

Visa and immigration policies

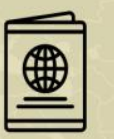

Allow dual intent for students

(section 214(b) exemption)

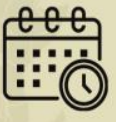

Match visa validity_periods

with program durations

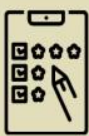

Point-based system to achieve

permanent residency

Figure 2: Summary of the proposed recommendations to strategically recruit and retain STEM international doctoral students.

status. This would eliminate the need for additional visa applications and work authorization before obtaining permanent residency.

For a more transparent pathway to permanent residency, we recommend adopting a well-defined point-based metric system, as is used by countries like Canada, Australia, and the U.K. These countries use this system to evaluate education, work experience, language fluency, existing job offers, and adaptability of the applicants (CIC News 2015; van Onselen 2019; Australian Government Department of Home Affairs n.d.). For instance, an immigrant moving to Australia needs at least sixty points to be approved. They can check this online without the need for lawyers or additional bureaucracy. Having a doctorate and a high English proficiency (based on standardized test scores) already add up to forty points. Age, employment, and other qualifications account for the rest. Some may fear that such a system will lead to an unequal immigration system that excludes based on class and education. We recommend that this system apply primarily to employment-based immigrants (e.g., those seeking a transition to permanent residency from an F-1 or $\mathrm{H}$ -
$1 \mathrm{~b}$ visa). In contrast to the plan introduced by the Trump administration, it should not apply to familybased petitioners, refugees, and asylees, or immigrants of other classes. Although it did not pass as an actual bill, the proposed "Build America Visa" plan would have repealed all family-sponsored immigration. It would have replaced all the employment-based permanent-residency categories for a point-based system, alongside proof of financial self-sufficiency, English proficiency, and a civics examination. While this plan had different aims than the ones we describe here, the idea could be used to support more international students. Using a similar system could reduce bias, uncertainty, and costs associated with current pathways toward U.S. citizenship. It will also reward international students who have invested time and financial resources into U.S. academic institutions and developed ties with their communities.

\section{ii. Training grants and other forms of financing}

Opening existing funding applications to non-U.S. citizens will help improve the recruitment and retention of international students who are otherwise unlikely to secure external funding. This 
initiative can eventually be expanded to developing new fellowships that specifically aim to increase cultural and geographic diversity. Richer cultural and geographic diversity correlates with higher rates of innovation, creativity, problem-solving, and entrepreneurship (Nathan and Lee 2013; Lorenzo et al. 2017). Supported by this evidence, we postulate that expanding federal funding opportunities to international doctoral students will increase academic productivity by cultivating more diverse working groups.

Without a significant increase in funding agencies' budget, however, allowing international Ph.D. students to apply for the same funding opportunities as domestic students will merely increase competition. The optimal solution will thus combine expanded access to international students with strictly increased funding for these opportunities and outcome measures for consistent evaluation. The implementation of this general policy would be highly specific to each funding agency and funding mechanism. We, therefore, recommend preliminary studies to estimate the number of new international students followed by concomitant increases to the number of opportunities. This increase in funding opportunities will not only provide international students with a new venue of funding but will also count as an investment towards decades of future American STEM research outputs. Additional resources may come from an internal reorganization that would increase budget share dedicated to training, or from the increased overall budget of each funding agency.

Importantly, increases in government funding for international students should not raise concerns about sponsoring foreigners with taxpayer money. As residents for tax purposes, international graduate students pay the same income taxes as domestic students. Indeed, the Internal Revenue Service requires universities to withhold $14 \%$ in taxes from stipends paid to international graduate students as "non-resident aliens" unless exempted under a tax treaty. We estimate that international students enrolled in Ph.D. programs alone contribute over $\$ 200$ million per year to the U.S. federal tax revenue, after subtracting tax returns. Overall, the aggregate economic impact of international students is significant. The most recent analysis by the National Association of Foreign Student Advisers (NAFSA) suggests that international graduate and undergraduate students collectively contributed approximately $\$ 38.7$ billion to the U.S. economy and supported 415,996 jobs for the 2019-2020 academic year (NAFSA 2020). With the proposed opportunities to fund international students, we envision a more diverse, stronger, and more open research climate for the U.S. Ultimately, this amounts to an investment in the nation's own future success.

The U.S. could emulate other countries that have prioritized international recruitment by offering government fellowships open to international graduate students. Since 2008, the government of Canada has issued Vanier Canada Graduate Scholarships for all doctoral students to study in Canada. The program includes no citizenship requirements. This scholarship initiative was created to attract top talent from the globe, without limiting eligibility solely based on one's place of birth-a key criterion over which students have no control. The government of Australia similarly announced in 2019 the "Destination Australia" scholarship without citizenship requirements for students to study in parts of Australia (Australian Government Department of Education). We believe these government-directed initiatives have contributed to the increase of international student enrollment in these countries. Such an initiative could even be used to ensure top academic talent is more evenly spread throughout the U.S.

\section{Conclusion}

For a country as large as the United States to continue accelerated economic growth, it needs to invest in the best talent the world can offer. We believe that investing in early career scientists, engineers, and entrepreneurs from abroad is the most cost-effective and efficient way to achieve that. We reiterate that international graduate students must be considered not only as future workers but also as future entrepreneurs and innovators, creating a positive ripple effect on the U.S. economy and employment rate. Here, we propose non-monetary and monetary solutions to help lower the entry barrier for new students and to retain graduates of STEM Ph.D. programs (Figure 2). Easier and more transparent pathways toward permanent residency and expanded federal funding opportunities will incentivize international doctoral students to contribute their best to STEM innovations in the U.S. 
We envision applying similar approaches to recruiting international students at all levels of graduate and professional study in the future. These concrete solutions directed at Congress and funding agencies will ensure the U.S. remains a competitive scientific beacon for the rest of the twenty-first century and beyond.

\section{Appendix: Sources for Figure 1}

United States (red square): National Center for Science and Engineering Statistics, Survey of Graduate Students and Postdoctorates in Science and Engineering: Fall 2018 (Table 1-3a).

Canada (brown triangle): Statistics Canada. Table 37-10-0018-01 Postsecondary enrollments, by registration status, institution type, status of student in Canada and gender. Includes data for the following disciplines: Physical and Life Sciences and Technologies, Mathematics, Computer and Information Sciences, Architecture, Engineering and related technologies, Agriculture, Natural Resources and Conservation, and Health and related fields.

Australia (blue circle): Australia Government Department of Education, Skills and Employment - Higher Education Statistics Data Cube (uCube). Includes data for the following disciplines: Natural and Physical Sciences, Information Technology, Engineering and related technologies, Agriculture Environmental and related studies, and Health.

\section{References}

Antonio, Anthony Lising, Mitchell J. Chang, Kenji Hakuta, David A. Kenny, Shana Levin, and Jeffrey F. Milem. "Effects of Racial Diversity on Complex Thinking in College Students." Psychological Science 15, no. 8 (2004): 507-10. https://doi.org/10.1111/i.09567976.2004.00710.x.

Australian Government Department of Education, Skills and Employment. "Destination Australia." Last modified December 16, 2020. Accessed April 1, 2021.

https://www.education.gov.au/destinationaustralia.

Australian Government Department of Home Affairs. "Points table for Skilled Independent visa (subclass 189)." Accessed April 1, 2021. https://immi.homeaffairs.gov.au/visas/getting-avisa/visa-listing/skilled-independent189/points-table.

Azoulay, Pierre, Benjamin Jones J., Daniel Kim, and Javier Miranda. "Immigration and Entrepreneurship in the United States." Working Paper No. 27778, National Bureau of Economic Research (2020). https://doi.org/10.3386/w27778

Bretschneider S., and Yiqun Dai. "Why do foreign citizens with US Ph.D. Degrees return home?" Center for Organization Research and Design, Arizona State University. Retrieved from https://cord.asu.edu/sites/default/files/wpcontent/uploads/2017/03/Why-do-foreigncitizens-with-US-PhD-CORD-website-version.pdf.

Citizenship and Immigration Canada (CIC) News. "Immigration to Canada Through A Provincial Program." February 18, 2015. Last modified August 31, 2020. Accessed April 1, 2021. https://www.cicnews.com/2015/02/immigratio n-canada-provincial-program024553.html\#ZOyqZAQoJALhL7AI.99.
Chen, Liang-Hsuan. "East-Asian Students' Choice of Canadian Graduate Schools." International Journal of Educational Advancement 7 (2007): 271-306. https://doi.org/10.1057/palgrave.ijea.2150071.

Eder, Judith, Wayne W. Smith, and Robert E. Pitts. "Exploring factors influencing student study abroad destination choice." Journal of Teaching in Travel \& Tourism 10, no. 3 (2010): 232-250. https://doi.org/10.1080/15313220.2010.50353 4.

Ewers, Michael C. and Joseph M. Lewis. "Risk and the Securitisation of Student Migration to the United States." Royal Dutch Geographical Society 99 no. 4 (2008): 470-82. https://doi.org/10.1111/i.14679663.2008.00474.x.

Heggeness, Misty L., Donna K. Ginther, Maria I. Larenas, and Frances D. Carter-Johnson. "The Impact of Postdoctoral Fellowships on a Future Independent Career in Federally Funded Biomedical Research." Working Paper No. 24508, National Bureau of Economic Research (2018). https://doi.org/10.3386/w24508.

Hourihan, Matt. "Update: In the Age of Trump, Congress Keeps Boosting Science Funding." American Association for the Advancement of Science, December 17, 2019. Accessed April 1, 2021. https://www.aaas.org/news/update-age-trumpcongress-keeps-boosting-science-funding.

Jaffe, Alexandria. "Path to citizenship in new Democratic immigration bill." Associated Press, February 18, 2021. Retrieved from https://apnews.com/article/biden-democratsnew-immigration-billb80ff43f84438d487f274abb93b0447d. 
Kandel, William A. "The Employment-Based Immigration Backlog." Congressional Research Service, March 26, 2020. Retrieved from https://fas.org/sgp/crs/homesec/R46291.pdf.

Lazio, Rick, and Harold Ford Jr. "The U.S. Needs to Prepare Workers for STEM Jobs." The Society for Human Resource Management, June, 6, 2019. Retrieved from

https://www.shrm.org/hr-today/news/hrmagazine/summer2019/pages/the-u.s.-needsto-prepare-workers-for-stem-jobs.aspx.

Lorenzo, Rocío, Nicole Voigt, Karin Schetelig, Annika Zawadzki, Isabelle Welpe, and Prisca Brosi. "The Mix That Matters." The Boston Consulting Group Global, April 26, 2017. Retrieved from https://www.bcg.com/publications/2017/peopl e-organization-leadership-talent-innovationthrough-diversity-mix-that-matters.

Nathan, Max, and Neil Lee. "Cultural Diversity, Innovation, and Entrepreneurship: Firm-Level Evidence from London." Economic Geography 89, no. 4 (2013): 367-94. https://doi.org/10.1111/ecge.12016.

National Center for Science and Engineering Statistics (NCSES). "Doctorate Recipients from U.S. Universities: 2019." NSF 21-308. Alexandria, VA: National Science Foundation. Retrieved from https://ncses.nsf.gov/pubs/nsf21308/.

National Center for Science and Engineering Statistics (NCSES). "Science and Engineering Indicators 2020: The State of U.S. Science and Engineering." NSB-2020-1. Alexandria, VA. Retrieved from https://ncses.nsf.gov/pubs/nsb20201/.

National Association of Foreign Student Advisers (NAFSA). "NAFSA International Student Economic Value Tool." November 2020. Retrieved from https://www.nafsa.org/policy-andadvocacy/policy-resources/nafsa-internationalstudent-economic-value-tool-v2.

National Research Council. "Policy Implications of International Graduate Students and Postdoctoral Scholars in the United States." Washington, DC: The National Academies Press, 2005.

https://doi.org/10.17226/11289.
National Science Board (NSB). "Science \& Engineering Indicators 2018." January 2018. Accessed April 1, 2021. Alexandria, VA: National Science Foundation (NSB-2018-1). Retrieved from https://www.nsf.gov/statistics/2018/nsb20181

Roach, Michael, and John Skrentny. "Rethinking immigration policies for STEM doctorates." Science 371, no. 6527 (2021): 350-352. https://doi.org/10.1126/science.abe7151.

Urais, David, and Carol Camp Yeakey. "Analysis of the U.S. Student Visa System: Misperceptions, Barriers, and Consequences." Journal of Studies in International Education 13, no. 1 (2008): 72-109. https://doi.org/10.1177/1028315307308135.

U.S. Citizenship and Immigration Services (USCIS). "Historical National Median Processing Time (in Months) for All USCIS Offices for Select Forms By Fiscal Year: Fiscal Year 2017 to 2021 (up to February 28, 2021)." Accessed April 1, 2021. Retrieved from https://egov.uscis.gov/processingtimes/historic-pt.

U.S. Department of State. "U.S. Visa: Reciprocity and Civil Documents by Country." Accessed April 1, 2021. Retrieved from https://travel.state.gov/content/travel/en/usvisas/Visa-Reciprocity-and-Civil-Documents-byCountry.html.

van Onselen, Leith. "Why Australia attracts so many international students." MacroBusiness, October 1, 2019. Retrieved from https://www.macrobusiness.com.au/2019/10/w hy-australia-attracts-so-many-internationalstudents/.

Yang, Molly. "What attracts mainland Chinese students to Australian higher education." Studies in Learning, Evaluation, Innovation and Development 4, no. 2 (2007): 1-12.

Zavodny, Madeline. "International students, STEM OPT, and the U.S. STEM Workforce." National Foundation for American Policy (NFAP). NFAP Policy Brief, March 2019. Retrieved from http://nfap.com/wpcontent/uploads/2019/03/InternationalStudents-STEM-OPT-And-The-US-STEMWorkforce.NFAP-Policy-Brief.March-2019.pdf.

Nuri Jeong is an international Ph.D. candidate in the Neuroscience Graduate Program at Emory University. Her dissertation research aims to understand the neural mechanisms of learning and novel memory formation in adulthood. She holds two B.S. degrees in Allied Health and Biotechnology from a partnership program between Immaculata University and Thomas Jefferson University. Nuri is originally from South Korea.

Esra Sefik is an international Ph.D. candidate in the Neuroscience Graduate Program at Emory University. Her doctoral work investigates clinical and genetic high-risk states for vulnerability to psychotic disorders, 
including schizophrenia. She holds a B.A. in clinical psychology from Tufts University. She is originally from Istanbul, Turkey, and is a dual citizen of Turkey and Bulgaria.

Fu Hung Shiu is an international Ph.D. candidate in the Neuroscience Graduate Program at Emory University. In his doctoral work, he examines the contribution of a $\mathrm{G}$ protein-coupled receptor to neurological disorders and brain development. He also holds a B.S. in Materials Science \& Engineering from Georgia Institute of Technology. He is originally from Hong Kong, China.

Thiago Arzua is an international Ph.D. candidate in the Neuroscience Doctoral Program at the Medical College of Wisconsin. His research focuses on human stem cell-derived brain organoids and disease modeling - more specifically Fetal Alcohol Spectrum Disorders. Before that, he completed his Bachelor's degree in Chemistry, with a minor in French, at the University of South Florida. He is originally from Curitiba, Brazil.

\section{Acknowledgments}

The authors are grateful for the contributions of George Andrew S. Inglis, Eric M. Feltham, and Robert P. Webber in providing suggestions and reviewing this manuscript.

\section{Disclaimer}

The authors disclose that they have no conflict of interest. 